\title{
Interactive comment on "Relationship between Chemical Composition and Oxidative Potential of Secondary Organic Aerosol from Polycyclic Aromatic Hydrocarbons” by Shunyao Wang et al.
}

\section{Anonymous Referee \#2}

Received and published: 6 December 2017

The comment was uploaded in the form of a supplement:

https://www.atmos-chem-phys-discuss.net/acp-2017-1012/acp-2017-1012-RC2-

supplement.pdf

Interactive comment on Atmos. Chem. Phys. Discuss., https://doi.org/10.5194/acp-2017-1012, 2017. 